Terakreditasi: SK No.: 60/E/KPT/2016

Website : http://ejournal.undip.ac.id/index.php/reaktor/

Reaktor, Vol. 17 No. 1, Maret Tahun 2017, Hal. 17-24

\title{
Pengaruh Konsentrasi NaOH dan Waktu Penahanan Terhadap Karakteristik Zeolit yang Disintesis dari Limbah Geothermal
}

\author{
Sulardjaka*) dan Deni Fajar Fitriyana \\ Departemen Teknik Mesin, Fakultas Teknik Universitas Diponegoro \\ Jl. Prof. Soedarto, SH, Tembalang, Semarang \\ Telp./Fax. (024)7460059 / (024)7460059 \\ ${ }^{*}$ Penulis korespondensi: sulardjaka@undip.ac.id
}

\begin{abstract}
THE EFFECT OF CONCENTRATION OF NaOH AND HOLDING TIME ON CHARACTERISTIC OF ZEOLIT SINTHESIZED FROM GEOTHERMAL WASTE. Objective of this research is to investigate the effect of concentration of $\mathrm{NaOH}$ and holding time on the characteristic of synthesized zeolite from geothermal waste. Geothermal waste was used as silica source and hydrothermally processed for zeolite synthesized. Variation concentration of $\mathrm{NaOH}$ was 1.67, 3, and $5 \mathrm{M}$ and variation of holding time are 1,3 , and 5 hours. Synthesized products were characterized by XRD, FTIR and SEM photomicrograph. It can be concluded that the rise of concentration of $\mathrm{NaOH}$ reduce the cristalization time and crystal size. Increasing of concentration of $\mathrm{NaOH}$ and holding time produce divers zeolite structure. At holding time $5 \mathrm{~h}$ and $\mathrm{NaOH} 1.67 \mathrm{M}$ produces zeolite A. At holding time 5 h and $\mathrm{NaOH}$ concentration $3 \mathrm{M}$ produce zeolite P. Sodalite is produced at concentration $\mathrm{NaOH}$ $5 \mathrm{M}$ with holding time $5 \mathrm{~h}$.
\end{abstract}

Keywords: hydrothermal; geothermal waste; zeolite

\begin{abstract}
Abstrak
Penelitian ini bertujuan untuk meneliti pengaruh konsntrasi $\mathrm{NaOH}$ dan waktu penahanan terhadap karakteristik zeolit yang disintesis dari limbah geothermal. Limbah geothermal dipilih sebagai bahan silika pada sintesis zeolit dengan metode hidrothermal. Penelitian dilakukan dengan variasi konsentrasi NaOH: 1,67, 3, dan $5 \mathrm{M}$, dan variasi waktu penahanan 1, 3 dan 5 jam. Produk hasil sintesis dikarakterisasi dengan XRD, FTIR dan foto SEM. Hasil dari penelitian ini menunjukkan bahwa tinggi konsentrasi NaOH kristalisasi zeolit A semakin cepat, sehingga ukuran kristal semakin kecil. Konsentrasi $\mathrm{NaOH}$ yang semakin tinggi dan waktu penahanan yang semakin lama, menghasilkan jenis struktur zeolit yang lebih beragam. Pada waktu penahanan 5 jam, variasi konsentrasi $\mathrm{NaOH} \mathrm{1,67} \mathrm{M}$ menghasilkan zeolit A, variasi konsentrasi $\mathrm{NaOH} 3 \mathrm{M}$ menghasilkan zeolit P (NaP1) dan pada variasi konsentrasi $\mathrm{NaOH} 5 \mathrm{M}$ menghasilkan sodalit.
\end{abstract}

Kata kunci: hydrothermal; limbah geothermal; zeolit

How to Cite This Article: Sulardjaka dan Fitriyana, D.F., (2017), Pengaruh Konsentrasi NaOH dan Waktu Penahanan Terhadap Karakteristik Zeolit yang Disintesis dari Limbah Geothermal, Reaktor, 17(1), 17-24, http://dx.doi.org/10.14710/reaktor.17.1.17-24 


\section{PENDAHULUAN}

Zeolit adalah senyawa alumino-silikat berhidrat dengan kation natrium, kalium dan barium. Zeolit juga sering disebut sebagai molecular sieve karena zeolit memiliki pori-pori berukuran molekuler (microporous) sehingga mampu memisahkan/menyaring molekul dengan ukuran tertentu. Zeolit mempunyai beberapa sifat antara lain: mudah melepas air akibat pemanasan, tetapi juga mudah mengikat kembali molekul air dalam udara lembab (Rahman dan Hartono, 2004). Zeolit juga mudah melepas kation dan diganti dengan kation lainnya (ion exchenge), misal zeolit melepas natrium dan digantikan dengan mengikat kalsium atau magnesium. Di dalam air, zeolit mampu mengikat bakteri E.Coli (Yudhastuti, 1993). Zeolit yang berkualitas tinggi dapat digunakan untuk mengikat air pada gas alam, untuk meningkatkan kualitas produk gas alam (Shirazian dan Ashrafizadeh, 2015).

Zeolit terdiri dari 2 macam, yaitu zeolit alam dan zeolit hasil sintesis. Saat ini zeolit hasil sintesis lebih banyak digunakan karena kemurnian, keseragaman struktur kristal dan ukuran partikel (Georgiev dkk., 2009). Zeolit dapat disintesis dengan metode sintesis hidrothermal. Proses hidrothermal merupakan proses sintesis di dalam sebuah reaktor (autoclave) baja yang dilapis Teflon $^{\circledR}$, pada suhu dan waktu tertentu (Bayuseno dkk., 2009; Wang dkk., 2016). Sintesis zeolit dengan proses ini, dilakukan dengan membuat larutan silika dan alumina dengan ataupun tanpa katalis dipanaskan sampai temperatur antara $150-300^{\circ} \mathrm{C}$ selama 24-240 jam (Donahoe dkk., 1984). Produk zeolit tergantung pada perbandingan $\mathrm{Al} / \mathrm{Si}$, temperatur sintesis, pelarut, PH dan katalis (Konde dan Thomson, 2007).

Permasalahan pada proses sintesis zeolit adalah mahalnya harga bahan silika (Georgiev dkk., 2009). Untuk mengatasi masalah tersebut, berberapa penelitian untuk menekan biaya pembuatan (sintesis) zeolit dengan mencari berbagai bahan silika yang murah telah dilakukan. Bahan awal (starting precursor) yang mulai diteliti/dikembangkan sebagai bahan silika pada sintesis zeolit adalah abu sekam padi (Bhavorthanayod dan Rungrojchaipon, 2009; Rahman dkk., 2009; Santasnachok dkk., 2015; Ng dkk., 2015). Bahan limbah lain yang juga berhasil disintesis menjadi zeolit adalah limbah abu terbang batubara. Limbah abu terbang batubara mengandung $45 \% \quad \mathrm{SiO}_{2}$. Sintesis zeolit dengan menggunakan limbah abu terbang batubara sebagai bahan $\mathrm{SiO}_{2}$ telah banyak dilakukan (Querol dkk., 2002; Adamczyk dan Bialecka, 2005; Cardoso dkk., 2015; Li dkk., 2015; Deng dkk., 2016; Fukasawa dkk., 2017;). Machado dan Miotto (2005) telah berhasil mensintesis limbah abu serpihan minyak (oil shale) yang mengandung $56 \% \mathrm{SiO}_{2}$ menjadi zeolit.

Penelitian yang dilakukan oleh Adamczyk dan Bialecka (2005) menghasilkan dua jenis zeolit, yaitu zeolit NaP1 dan analcime. Sintesis ini menggunakan larutan 3,6\% $\mathrm{Na}_{2} \mathrm{O}(1,16 \mathrm{M} \mathrm{NaOH})$ dengan suhu hydrothermal $80-320^{\circ} \mathrm{C}$. Kristal zeolit NaP1 dan analcime mulai terbentuk pada suhu $120^{\circ} \mathrm{C}$. Dengan peningkatan suhu hydrothermal kandungan zeolite NaP1 semakin meningkat, dan untuk suhu 200 sampai $320^{\circ} \mathrm{C}$, zeolit analcime mengalami pertumbuhan yang signifikan. Penelitian pengaruh konsentrasi $\mathrm{NaOH}$ dalam sintesis zeolit dengan bahan dasar abu terbang batu bara telah dilakukan oleh Wang dkk. (2008). Pada penelitian ini, sintesis zeolit dilakukan dengan variasi konsentrasi $\mathrm{NaOH}$ sebesar: 1,$67 ; 3 ; 5$; dan $6,67 \mathrm{M}$ dengan suhu hydrothermal sebesar $100^{\circ} \mathrm{C}$. Proses sintesis dilakukan dengan variasi waktu: 340, 250 dan 190 menit. Penelitian ini menyimpulkan bahwa peningkatan konsentrasi $\mathrm{NaOH}$ menyebabkan kristal dari zeolit A akan menurun karena \%kristalinitas akan semakin tinggi. Hasil penelitian yang dilakukan oleh Escalante dkk. (1999) menunjukkan bahwa terdapat kandungan silika yang terdapat pada limbah geothermal. Penelitian ini bertujuan untuk meneliti pengaruh molaritas $\mathrm{NaOH}$ terhadap karakteristik zeolit yang disintesis dari limbah. Pada penelitian terdahulu, telah berhasil disintesis zeolit dari bahan dengan suhu hydrothermal 100,110 dan $120^{\circ} \mathrm{C}$ dengan waktu hidrothermal 5 jam dan variasi waktu hidrothermal 3, 4 , dan 5 jam dengan temperatur hidrothermal $120^{\circ} \mathrm{C}$ (Sulardjaka dkk., 2014).

\section{BAHAN DAN METODE Bahan}

Sintesis zeolit pada penelitian ini menggunakan bahan baku limbah dari pembangkit listrik tenaga panas bumi. Limbah geothermal diambil dari tempat penimbunan limbah geothermal PT Geo Dipa Energy, Dieng, Wonosobo. Untuk proses pembuatan precursor pembuatan zeolit digunakan larutan $\mathrm{NaOH}$ dan $\mathrm{Al}(\mathrm{OH})_{3}$.

\section{Prosedur Penelitian}

Limbah geothermal kemudian dikeringkan dan diayak dengan ayakan berukuran mesh 100. Serbuk limbah geotermal tersebut kemudian dikalsinasi dengan dipanaskan pada suhu $850^{\circ} \mathrm{C}$ di lingkungan dengan oksigen selama 3 jam. Proses ini bertujuan untuk menghilangkan kandungan air atau pengotor lain, sehingga didapat serbuk dengan kandungan silika yang tinggi. Produk hasil proses kalsinasi limbah geotermal diuji komposisi dengan metode AAS dengan menggunakan alat uji AAS Shimadzhu tipe AA-6650. Pengujian komposisi dengan menggunakan AAS dilakukan pada serbuk yang tidak dikalsinasi dan dikalsinasi. Pengujian ini mendapatkan perbedaan komposisi senyawa yang terkandung pada bahan baku limbah geothermal. Tahap berikutnya adalah pembuatan larutan natrium aluminat. Pembuatan larutan natrium aluminat dimulai dengan melarutkan 20 gr $\mathrm{NaOH}$ kedalam $100 \mathrm{~mL}$ aquades. Larutan yang terbentuk kemudia dimasukan ke dalam gelas kaca, dan diaduk dengan magnetic stirrer pada suhu $100{ }^{\circ} \mathrm{C}$ dan kecepatan putaran $300 \mathrm{rpm}$. Pada saat pengadukan, ke dalam larutan ditambahkan 8,5 gr $\mathrm{Al}(\mathrm{OH})_{3}$. Sebanyak $30 \mathrm{ml}$ larutan natrium aluminat dicampur dengan 30 $\mathrm{mL}$ larutan $\mathrm{NaOH}(5,3$, atau 1,67 M) kemudian 
ditambah dengan 3 gr serbuk geothermal yang telah dikalsinasi. Campuran larutan tersebut kemudian diaduk dengan menggunakan magnetic stirer yang telah diatur pada suhu $30^{\circ} \mathrm{C}$ dengan kecepatan putaran sebesar $300 \mathrm{rpm}$.

Natrium silikat yang dihasilkan dimasukkan ke dalam tabung Teflon ${ }^{\circledR}$ kemudian ditempatkan pada alat hydrothermal. Proses sintesis dimulai dengan pemanasan sampai suhu air didalam reaktor sebesar $100^{\circ} \mathrm{C}$, kemudian dilakukan penahanan dengan variasi waktu penahanan: 3, 4, atau 5 jam dalam keadaan tertutup rapat. Hasil yang terbentuk kemudian di saring dengan kertas saring whatmann untuk memisahkan antara padatan dan filtrate. Padatan yang terbentuk kemudian dicuci dengan aquabides. Selanjutnya padatan dikeringkan menggunakan oven pada suhu $100^{\circ} \mathrm{C}$ selama 6 jam. Untuk mengetahui pengaruh kondisi reaksi terhadap pembentukan zeolit dilakukan variasi waktu pemanasan pada proses hydrothermal.

Karakterisasi yang dilakukan pada produk hasil proses hidrothermal meliputi: analisis fasa kristalin pada zeolite dan penentuan ukuran butir zeolit dengan menggunakan X-Ray Difraction (XRD). Fourier Transform Infra-Red (FTIR) untuk identifikasi gugus fungsi ikatan dalam stuktur zeolit. Untuk menganalisis morfologi dan topologi serbuk zeolit, dilakukan dengan pengujian SEM.

\section{HASIL DAN PEMBAHASAN}

Hasil pengujian komposisi kimia serbuk limbah geothermal yang belum dikalsinasi (as receive) dan telah dikalsinasi (calcinated) ditunjukkan pada Tabel 1. Tabel 1 menunjukkan rata-rata kandungan $\mathrm{SiO}_{2}$ dan $\mathrm{Al}_{2} \mathrm{O}_{3}$ dalam serbuk geothermal yang belum dikalsinasi adalah 49,100\% dan 0,0559\%. Kandungan $\mathrm{SiO}_{2}$ dan $\mathrm{Al}_{2} \mathrm{O}_{3}$ adalah dua unsur utama yang akan digunakan sebagai parameter kelayakan penggunaan lumpur geothermal sebagai bahan dasar dalam proses sintesis zeolit. Data komposisi limbah geothermal yang belum dikalsinasi menunjukkan bahwa limbah geothermal berpotensi untuk disintesis menjadi zeolit. Hasil pengujian komposisi pada bahan limbah geothermal yang telah dikalsinasi, menunjukkan bahwa kandungan $\mathrm{SiO}_{2}$ dan $\mathrm{Al}_{2} \mathrm{O}_{3}$ pada limbah geothermal yang telah dikalsinasi meningkat secara drastis menjasi 80,04 dan 0,14. Menurut Yusof dkk. (2010) hal ini terjadi karena pada proses kalsinasi, terjadi proses penguapan senyawa organik, sehingga meningkatkan persentase senyawa anorganik terutama $\mathrm{SiO}_{2}$.

Tabel. 1. Komposisi kimia limbah geothermal (\%)

\begin{tabular}{cccccc}
\hline & $\mathrm{Al}_{2} \mathrm{O}_{3}$ & $\mathrm{Fe}_{2} \mathrm{O}_{3}$ & $\mathrm{Na}_{2} \mathrm{O}$ & $\mathrm{SiO}_{2}$ & Lainnya \\
\hline bahan baku & 0,06 & 0,20 & 0,60 & 49,10 & $-100 \%$ \\
terkalsinasi & 0,14 & 0,45 & 0,76 & 80,04 & $-100 \%$ \\
\hline
\end{tabular}

Gambar 1 dan Gambar 2 menunjukkan hasil pengujian XRD produk hidrothermal limbah geothermal dengan konsentrasi $\mathrm{NaOH}$ yang berbeda $(1,67,3$, dan $5 \mathrm{M})$ dengan suhu $100^{\circ} \mathrm{C}$ dan waktu penahanan 3 jam dan 4 jam. Grafik pada gambar tersebut menunjukkan terdapat intensitas yang menunjukkan terbentuknya struktur zeolit A. Zeolit A ditunjukkan dengan adanya puncak intensitas pada nilai 2 theta 18,665. Perbedaan intesitas puncak yang dominan pada setiap difraktogram tersebut, menunujukan adanya perbedaan kecepatan kristalisasi dari masing-masing zeolit yang dapat diketahui dari ukuran kristal yang dihasilkan pada setiap variasi konsentrasi $\mathrm{NaOH}$.

Hasil karakterisasi dengan XRD pada proses hidrothermal dengan variasi konsentrasi $\mathrm{NaOH}$ : 1,67, 3 , dan $5 \mathrm{M}$ pada suhu $100^{\circ} \mathrm{C}$ dan waktu pemanasan 5 jam ditunjukkan pada Gambar 3. Dari perbandingan difraktogram tersebut dapat dilihat bahwa intensitas yang menunjukkan keberadaan struktur zeolit A merupakan hasil yang dominan pada konsentrasi $\mathrm{NaOH}$ 1,67 M. Pada konsentrasi NaOH $3 \mathrm{M}$ dan $\mathrm{NaOH} 5 \mathrm{M}$ didominasi oleh masing-masing zeolit $\mathrm{P}$ ( NaP1) dan sodalit. Pada proses hidrothermal dengan waktu penahanan 5 jam, terbentuknya zeolit $\mathrm{A}$, zeolit $\mathrm{P}$ dan sodalit pada setiap variasi konsentrasi $\mathrm{NaOH}$ yang ditunjukkan peak dengan intensitas tertinggi pada 2 theta 28,180 dengan intesitas relatif sebesar 100 . Pembentukan sodalit ditunjukkan dengan peak dengan intensitas tertinggi pada 2 theta 24,502 dan pada variasi konsentrasi $\mathrm{NaOH} 5 \mathrm{M}$.

Hasil pengujian gugus ikatan terhadap hasil proses hidrothermal ditunjukkan pada Gambar 4, Gambar 5 dan Gambar 6. Terbentuknya kerangka zeolit pada hasil sintesis ditemukan pada sampel yang diuji dengan FTIR. Hal ini ditandai dengan puncak-puncak pada bilangan gelombang, antara lain: adanya regangan simetris O-Si-O atau O-Al-O yang muncul untuk semua variasi waktu pemanasan 3, 4 dan 5 jam muncul bilangan gelombang $740 \mathrm{~cm}^{-1}$. Vibrasi eksternal dari cincin ganda D4R atau D6R merupakan vibrasi yang menjadi ciri khas terbentuknya struktur zeolit A (Xu dkk., 2007). Pada variasi $\mathrm{NaOH} 1,67 \mathrm{M}$ dengan waktu pemanasan 3, 4, dan 5 jam dihasilkan peak dengan masing-masing panjang gelombang 509,21; 555,5; dan $509 \mathrm{~cm}^{-1}$ yang menunjukkan adanya vibrasi eksternal dari cincin D4R atau D6R pada serbuk yang dikarakterisasi. Sehingga dapat dikatakan bahwa pada perlakuan ini dihasilkan zeolit dengan jenis zeolit A. Puncak spektra untuk semua variasi waktu pemanasan 3, 4, dan 5 jam pada masing- masing bilangan gelombang 1018,$41 ; 1081,41 ; 1018 \mathrm{~cm}^{-1}$ menunjukkan adanya regangan asimetris $\mathrm{O}-\mathrm{Si}-\mathrm{O}$ atau $\mathrm{Al}-\mathrm{O}-\mathrm{Al}$. Regangan asimetris dan regangan simetris menunjukkan adanya perubahan panjang ikatan dari OSi-O atau O-Al-O. Semakin panjang ikatan molekul menunjukkan bahwa adanya peningkatan fleksibilitas dari atom yang saling berikatan (O-Si-O atau O-Al-O). Fleksibilitas dari ikatan O-Si-O atau O-Al-O sangat penting, karena merupakan ukuran derajat kebebasan yang memungkinkan pembentukan berbagai jenis struktur zeolit.

Gambar 7 menunjukkan pengaruh molaritas $\mathrm{NaOH}$ dan waktu penahanan terhadap ukuran kristal zeolit. Pada gambar tersebut dapat disimpulkan bahwa pada molaritas $\mathrm{NaOH} 1,67 \mathrm{M}$ memiliki kristalisasi 
yang berlangsung lebih lambat dibandingkan konsentrasi $\mathrm{NaOH} 3 \mathrm{M}$, hal ini ditunjukkan ukuran kristal yang lebih besar dibandingkan dengan ukuran kristal yang dihasilkan pada variasi $\mathrm{NaOH} 3 \mathrm{M}$. Hal yang berbeda ditunjukkan pada konsentrasi $\mathrm{NaOH} 5 \mathrm{M}$ yang menghasilkan ukuran kristal zeolit A yang lebih besar dibandingkan dengan ukuran kristal zeolit A yang

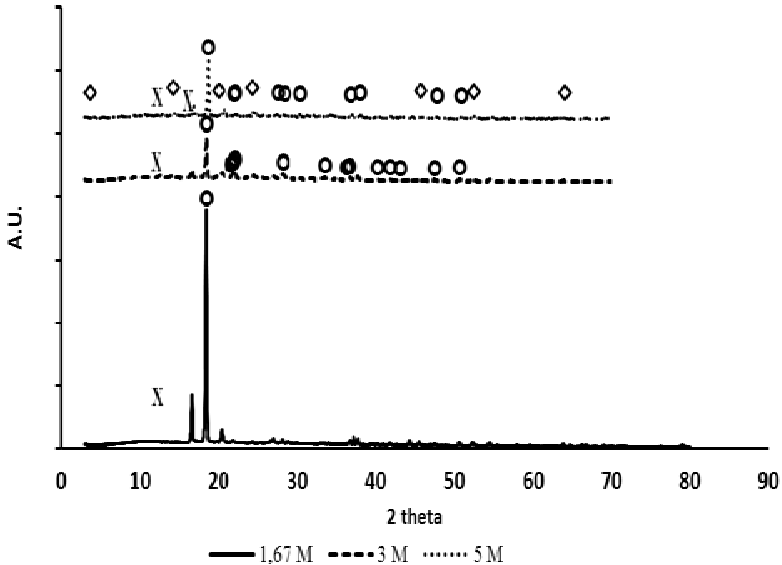

Gambar 1. XRD pengaruh \%M NaOH terhadap hasil sintesis dengan waktu hidrothermal 3 jam

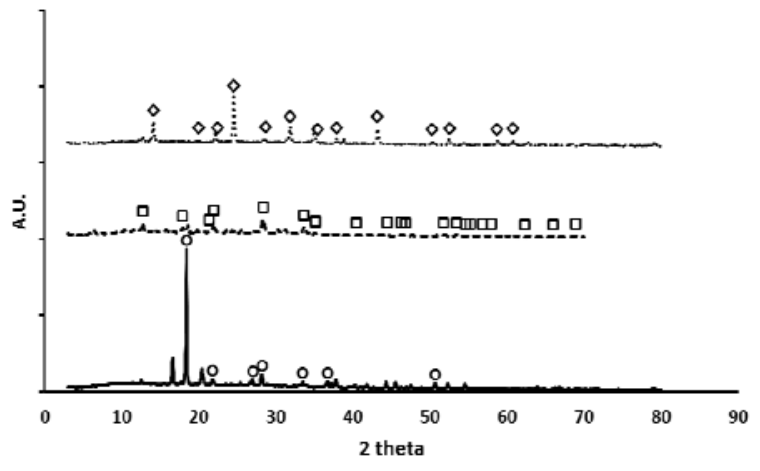

-1.67 M $\quad-. .3 \mathrm{M} \quad \ldots . . .5 \mathrm{M}$

Gambar 3. XRD pengaruh \%M NaOH terhadap hasil sintesis dengan waktu hidrothermal 5 jam

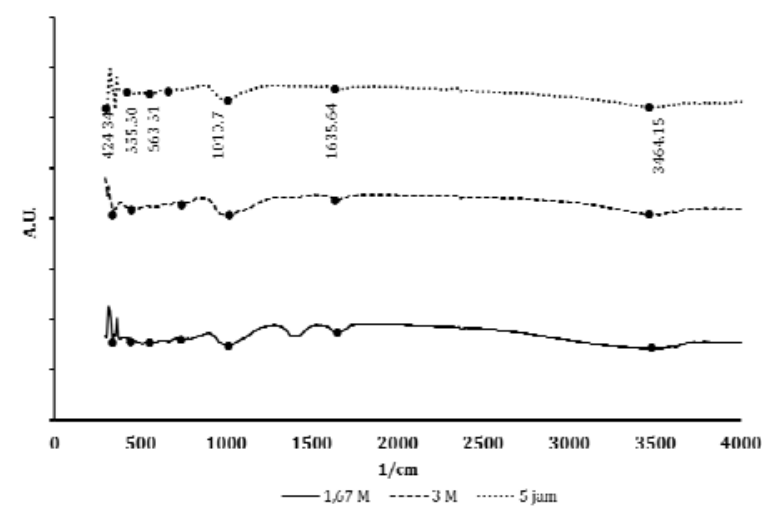

Gambar 5. FTIR analisis pengaruh \%M NaOH dengan waktu hidrothermal 4 jam dihasilkan pada variasi $\mathrm{NaOH}$ 1,67 M dan $\mathrm{NaOH} 3 \mathrm{M}$. Hal ini menunjukkan bahwa pada konsentrasi $\mathrm{NaOH} 5$ $\mathrm{M}$ proses kristalisasi zeolit A berlangsung lebih lambat jika dibandingkan dengan kristalisasi yang dihasilkan pada variasi konsentrasi $\mathrm{NaOH}$ 1,67M dan $\mathrm{NaOH} 3 \mathrm{M}$ sehingga menghasilkan ukuran kristal yang lebih besar.

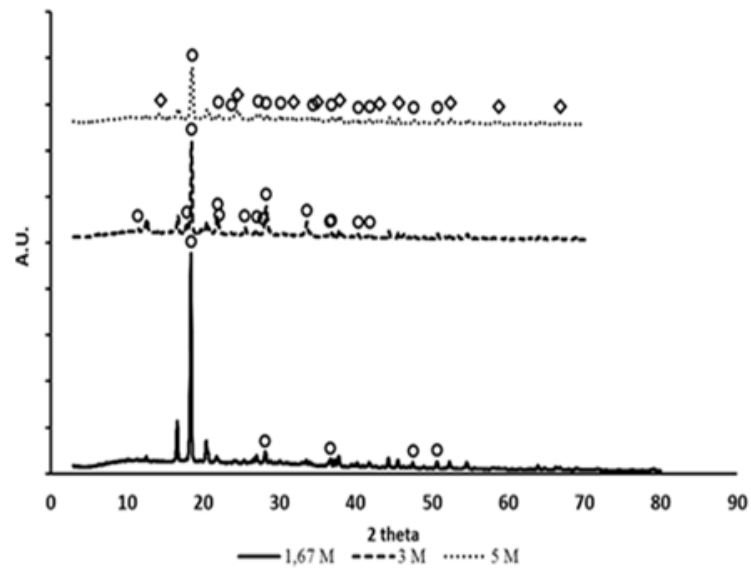

Gambar 2. XRD pengaruh \%M NaOH terhadap hasil sintesis dengan waktu hidrothermal 4 jam

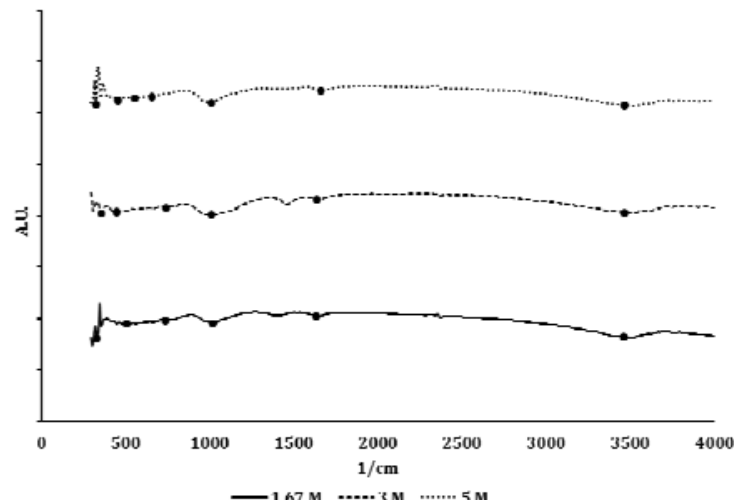

Gambar 4. FTIR analisis pengaruh \% $\mathrm{M} \mathrm{NaOH}$ dengan waktu hidrothermal 3 jam

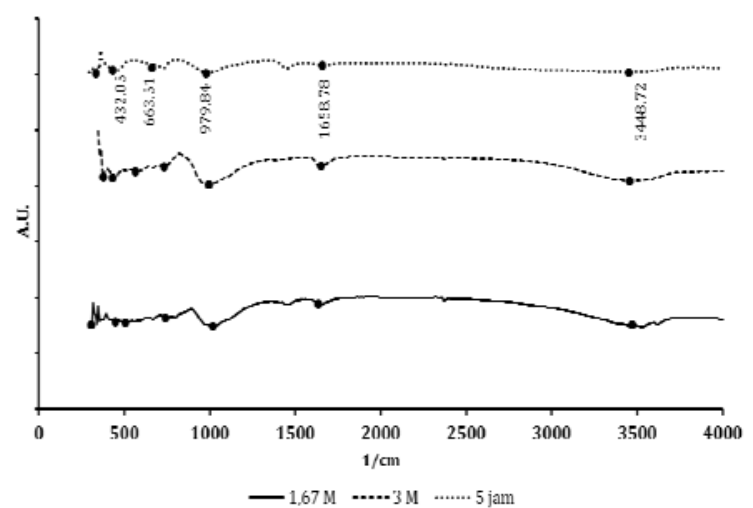

Gambar 6. FTIR analisis pengaruh $\% \mathrm{M} \mathrm{NaOH}$ dengan waktu hidrothermal 5 jam 


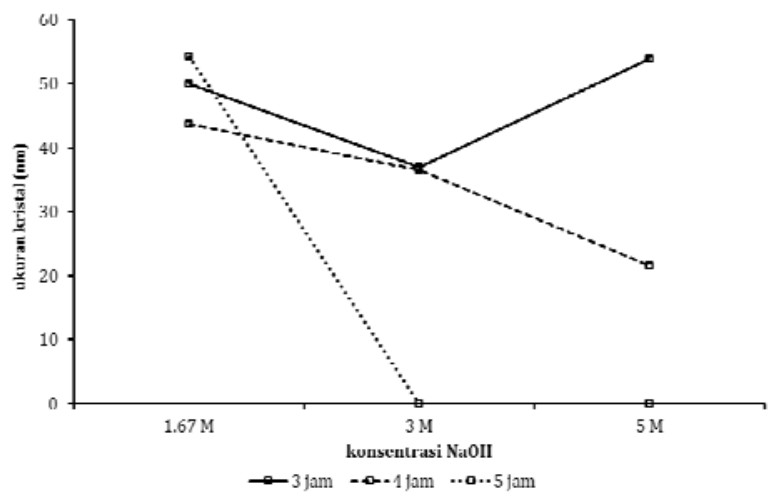

Gambar 7. Pengaruh konsentrasi $\mathrm{NaOH}$ terhadap ukuran kristal zeolit A

Pada konsentrasi $\mathrm{NaOH} 5 \mathrm{M}$ ditemukan adanya pertumbuhan kristal untuk zeolit jenis lain yaitu sodalit. Data untuk sodalit ditunjukkan dengan intensitas dominan nilai 2 theta 24,502. Dengan adanya pertumbuhan kristal sodalit, kristalisasi zeolit A pada konsentrasi $\mathrm{NaOH} 5 \mathrm{M}$ dengan waktu pemanasan 3 jam akan semakin lambat sehingga ukuran kristal yang dihasilkan lebih besar.

Vibrasi bengkokan Si-O atau Al-O menunjukkan adanya perubahan sudut ikatan pada Si$\mathrm{O}$ atau Al-O. Pada variasi waktu penahan 3 jam (Gambar 3) tidak ditemukan adanya perubahan sudut ikatan pada $\mathrm{Si}-\mathrm{O}$ atau Al-O, karena tidak adanya peak yang dihasilkan pada rentan panjang gelombang 420$500 \mathrm{~cm}^{-1}$. Sedangkan untuk variasi waktu pemanasan 4 dan 5 jam (Gambar 5 dan Gambar 6) ditemukan adanya perubahan sudut ikatan pada $\mathrm{Si}-\mathrm{O}$ atau Al-O yang masing-masing ditunjukkan pada bilangan gelombang 447,49 dan $447 \mathrm{~cm}^{-1}$.

Menurut Wajima dkk. (2005) kristal zeolit A mempunyai bentuk kubus karena disusun oleh polyhedra yang dihasilkan dari 4 cincin tetrahedra yang saling berikatan ganda (D4R). Hasil pengujian SEM seperti yang ditunjukkan pada Gambar 8 (a,b,c), Gambar 9 (a,b,c) dan Gambar 10 (a) menunjukkan adanya struktur zeolit A yang berbentuk kubus diantara partikel yang berbentuk spherical. Gambar 8c menunjukkan kristal zeolit A dengan bentuk kubik yang mendekati sempurna yang terbentuk pada waktu pemanasan 3 jam dengan $\mathrm{NaOH} 5 \mathrm{M}$. Hidrothermal dengan waktu penahanan 4 jam menghasilkan zeolit $\mathrm{A}$ berbentuk kubus pada semua variasi $\mathrm{NaOH}$ (Gambar 9 a,b,c). Pada waktu pemanasan 5 jam, zeolit A dihasilkan pada $\mathrm{NaOH}$ 1,67 M (Gambar 10a). Pada Gambar 10b dan Gambar 10c ditunjukkan gambar zeolit sintesis dengan variasi konsentrasi $\mathrm{NaOH} 3 \mathrm{M}$ dan $5 \mathrm{M}$ dan waktu pemanasan 5 jam. Pada Gambar 10b menunjukkan terbentuknya zeolit $\mathrm{P}$ sedangkan pada Gambar 10c menunjukkan bentuk morfologi struktur kristal sodalit.

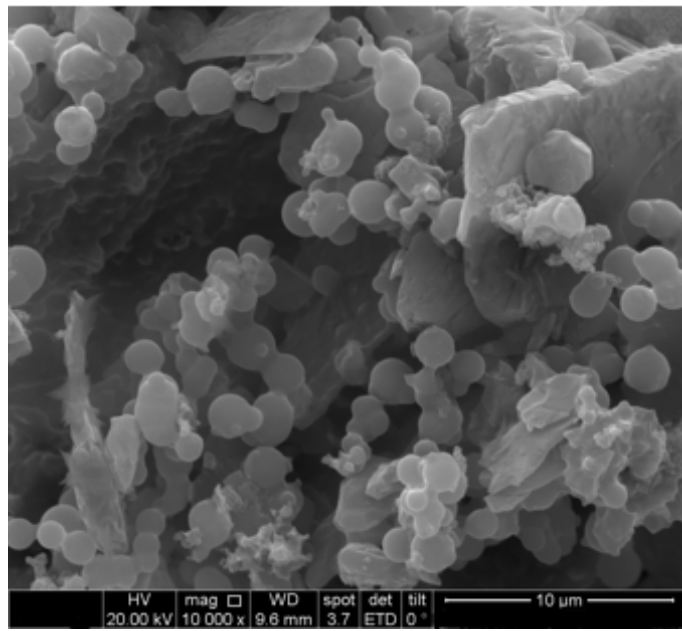

(a)

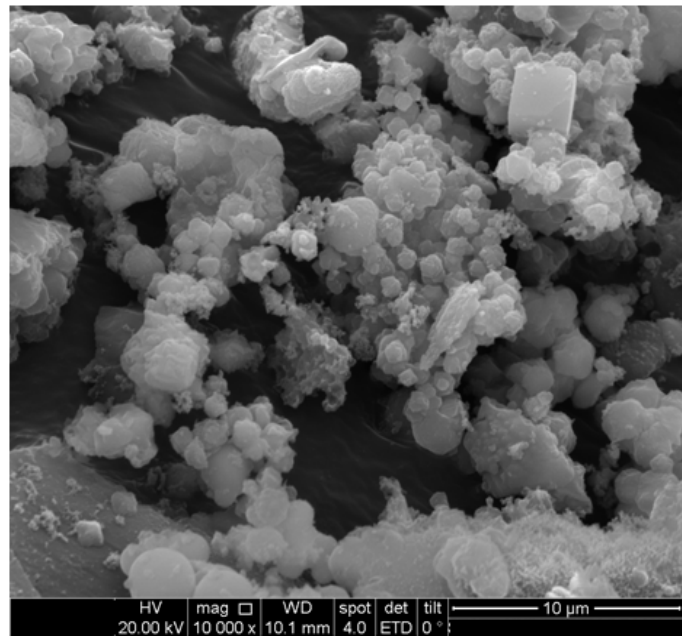

(b)

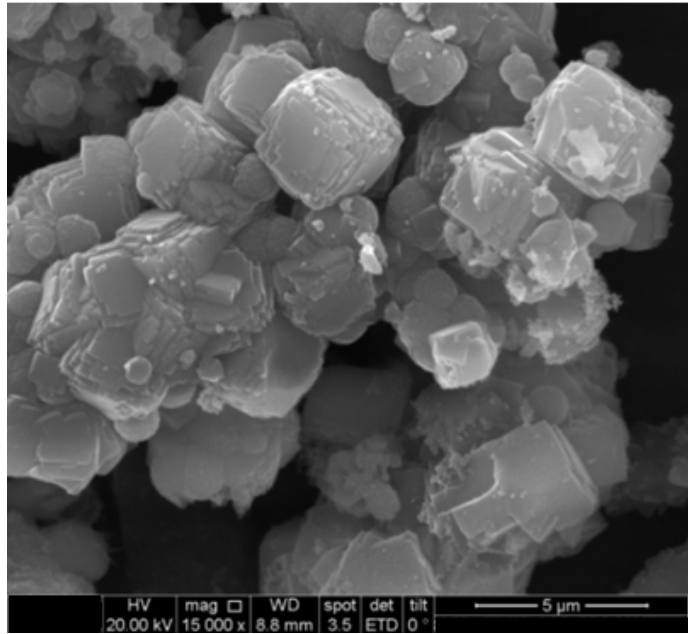

(c)

Gambar 8. Zeolit A produk hidrothermal pada suhu 100 waktu penahanan 3 jam (a) 1,67 M, (b) $3 \mathrm{M}$. dan (c) $5 \mathrm{M}$ 


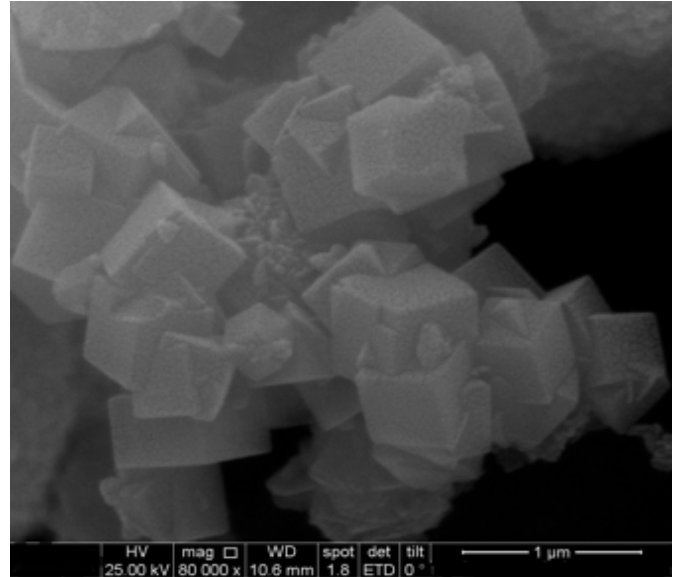

(a)

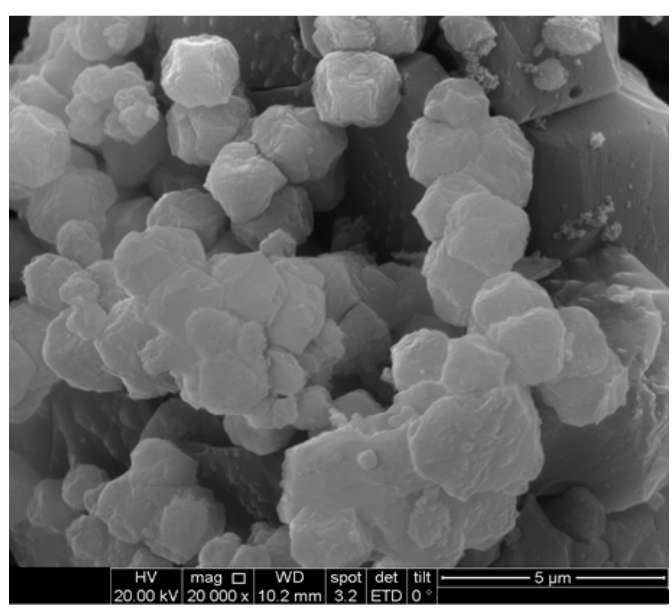

(b)

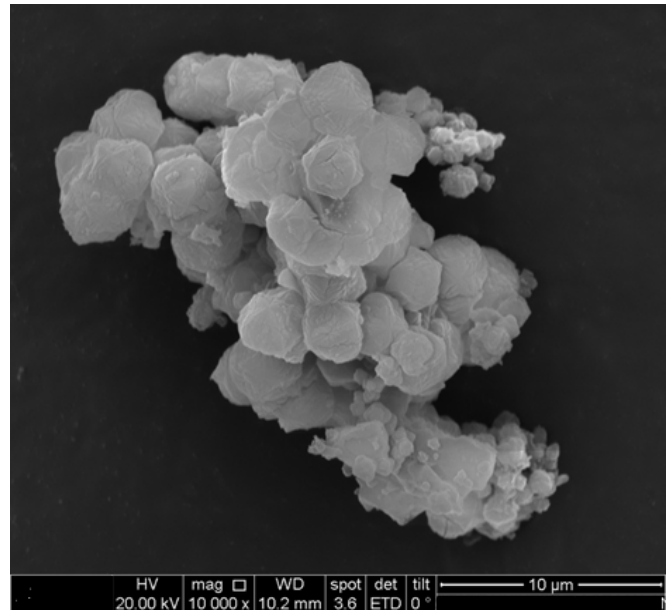

(c)

Gambar 9. Zeolit A produk hidrothermal pada suhu $100^{\circ} \mathrm{C}$ waktu penahanan 4 jam (a) 1,67 M; (b) $3 \mathrm{M}$; (c) $5 \mathrm{M}$

\section{KESIMPULAN}

Semakin tinggi konsentrasi $\mathrm{NaOH}$ mempercepat kristalisasi zeolit A sehingga menurunkan ukuran kristal. Konsentrasi $\mathrm{NaOH}$ yang semakin tinggi dan waktu penahanan yang semakin lama, mengarahkan pembentukan jenis struktur zeolit yang lebih beragam,

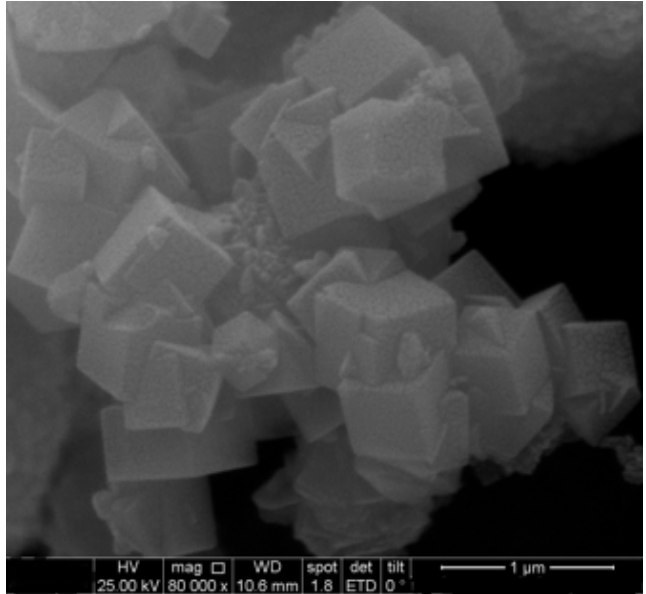

(a)

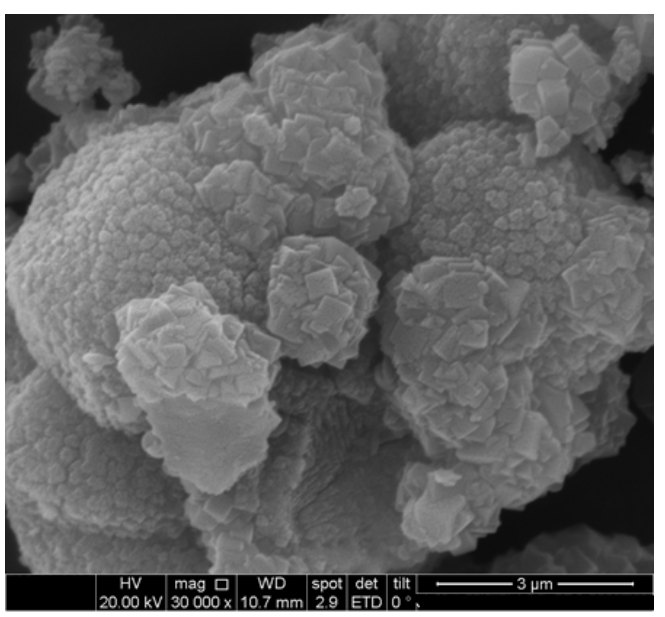

(b)

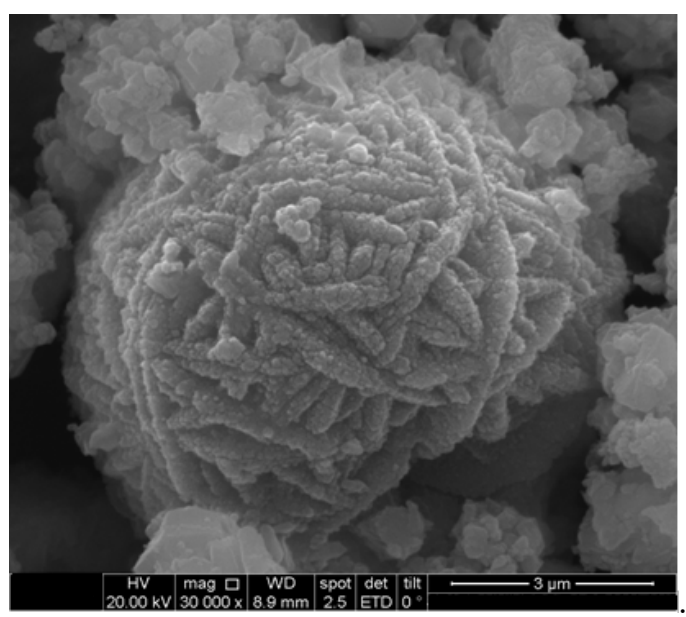

(c)

Gambar 10. Zeolit A produk hidrothermal pada suhu $100^{\circ} \mathrm{C}$ waktu penahanan 5 jam (a) 1,67 M; (b) $3 \mathrm{M}$;

(c) $5 \mathrm{M}$

seperti yang ditunjukan pada waktu penahanan 5 jam. Pada waktu penahanan 5 jam, variasi konsentrasi $\mathrm{NaOH}$ 1,67 M menghasilkan zeolit A, variasi konsentrasi $\mathrm{NaOH} 3 \mathrm{M}$ menghasilkan zeolit P (NaP1) dan pada variasi konsentrasi $\mathrm{NaOH} 5 \mathrm{M}$ menghasilkan sodalit. 


\section{UCAPAN TERIMA KASIH}

Penulis mengucapkan terima kasih kepada Fakultas Teknik Universitas Diponegoro, yang telah memberikan dana penelitian bagi kegiatan penelitian ini

\section{DAFTAR PUSTAKA}

Adamczyk, Z. and Bialecka, B., (2005), Hydrothermal Synthesis of Zeolites from Polish Coal Fly Ash, Polish Journal of Environmental Studies, 14(6), pp. 713-719.

Bayuseno, A.P., Schmahl. W.W., and Müllejans, Th., (2009), Hydrothermal Processing of MSWI Fly AshTowards New Stable Minerals and Fixation of Heavy Metals, Journal of Hazardous Materials, 167, pp. 250 259.

Bhavorthanayod, C. and Rungrojchaipon, P., (2009), Synthesis of Zeolite A Membrane from Rice Husk Ash, Journal of Metals, Materials and Minerals, 19(2), pp. 79-83.

Cardoso, A.M., Horn, M.B., Ferret, L.S., Azevedo, C.M.N., and Pires, M., (2015), Integrated Synthesis of Zeolites 4A and $\mathrm{Na}-\mathrm{P} 1$ Using Coal Fly Ash for Application in the Formulation of Detergents and Swine Wastewater Treatment, Journal of Hazardous Materials, 287, pp. 69-77

Deng, L., Xu, Q., Wu, H., (2016), Synthesis of ZeoliteLike Material by Hydrothermal and Fusion Methods Using Municipal Solid Waste Fly Ash, Procedia Environmental Sciences, 31, pp. 662-667.

Donahoe, R.J., Liou, J.G. and Guldman, S., (1984), Synthesis and Characterization of Zeolite in the System $\mathrm{Na} \sim \mathrm{O}-\mathrm{K}_{2} \mathrm{O}-\mathrm{Al}_{2} \mathrm{O}_{3}-\mathrm{SiO}_{2}-\mathrm{H} / \mathrm{O}$, Clays and Clay Minerals, 32(6), pp. 433-443.

Escalante, J.J, Mendoza, G., Mancha, H., López, J. and Vargas, G., (1999), Pozzolanic Properties of a Geothermal Silica Waste Material, Cement and Concrete Research, 29, pp. 623-625

Fukasawa, T., Karisma, A.D., Shibata, D., Huang, AnNi, Fukui, K., (2017), Synthesis of Zeolite from Coal Fly Ash By Microwave Hydrothermal Treatment With Pulverization Process, Advanced Powder Technology, In Press, Corrected Proof, Available online 30 December 2016, http://dx.doi.org/10.1016/ j.apt.2016.12.006.

Georgiev, D., Bogdanov, B., Angelova, K., Markovska, I., and Hristov, Y., (2009), Synthetic Zeolite Structure, Clasification, Current Trend in Zeolite Synthesis, Review, International Science Conference, 4th - 5th June 2009, Stara Zagora, Bulgaria.

Konde, S. and Thomson, R.W., (2007), Preparation of High-Silica Zeolite Beads From Silica Gel, B.Sc Thesis,
Dept. of Chemical Engineering, Worcester Polytechnic Institute.

Li, C., Zhong. H., Wang, S., Xue, J., and Zhang, Z., (2015), A Novel Conversion Process for Waste Residue: Synthesis of Zeolite from Electrolytic Manganese Residue and Its Application to the removal of Heavy Metals, Colloids and Surfaces A: Physicochem. Eng. Aspects, 470, pp. 258-267.

Machado, N.R.C.F. dan Miotto, D.M.M., (2005), Synthesis of Na-A and $-\mathrm{X}$ Zeolites from Oil Shale Ash, Fuel, 84, pp. 2289-2294.

Ng, Eng-Poh, Awala, H., Tan, Kok-Hou, Adam, F., Retoux, R., Mintova, S., (2015), EMT-type Zeolite Nanocrystals Synthesized from Rice Husk, Microporous and Mesoporous Materials, 204, pp. 204209.

Querol, X., Moreno, N., Umana, J.C., Alastuey, A., Hernandez, E., Lo'pez-Soler, and Plana, F., 2002, Synthesis of Zeolites from Coal Fly Ash: An Overview, International Journal of Coal Geology, 50, pp. 413423.

Rahman, A. dan Hartono, B., 2004, Penyaringan Air Tanah dengan Zeolit Alami untuk Menurunkan Kadar Besi dan Mangan, Makara seri Kesehatan, 8(1), hal. 16.

Rahman, M.M., Hasnida, N., and Wan, N., (2009), Preparation of Zeolite Y Using Local Raw Material Rice Husk as a Silica Source, J. Sci. Res., 1 (2), pp. 285 291.

Santasnachoka, C., Kurniawana, W., Hinode, H., (2015), The Use of Synthesized Zeolites from Power Plant Rice Husk Ash Obtained from Thailand as Adsorbent for Cadmium Contamination Removal from Zinc Mining, Journal of Environmental Chemical Engineering, 3(3), pp. 2115-2126.

Shirazian, S. and Ashrafizadeh, S.N., (2015), Synthesis of Substrate-modified LTA Zeolite Membranes for Dehydration of Natural Gas, Fuel, 148, pp. 112-119

Sulardjaka, Fitriyana, D.F., and Adi, A.P., (2014), Synthesis of Zeolite from Geothermal Waste, Applied Mechanics and Materials, 660, pp. 157-161.

Wajima, T., Hagaa, M., Kuzawa, K., Ishimoto, H., Tamadaa, O., Ito, K., Nishiyama, T., Downsd, R. T., Rakovan, J.F., 2005. Zeolite Synthesis from Paper Sludge Ash at Low Temperature $\left(90^{\circ} \mathrm{C}\right)$ with Addition of Diatomite. Journal of Hazardous Materials B, 132, pp. 244-252.

Wang, C.F., Sheng Li, J., Jun Wang, L., Sun, X. Y. (2008), Influence of $\mathrm{NaOH}$ Concentrations on Synthesis of Pure-Form Zeolite A from Fly Ash Using 
Two-Stage Method, Journal of Hazardous Materials, 155 , pp. 58-64.

Wang, Ji-Quang, Huang. Ya-Xi, Pan, Y., Mi, Jin-Xiao, (2016), New Hydrothermal Route for the Synthesis of High Purity Nanoparticles of Zeolite Y from Kaolin and Quartz, Microporous and Mesoporous Materials, 232, pp. 77-85.

Xu, R., Pang, W., Yu, J., Huo, Q., and Chen, J., (2007, Chemistry of Zeolites and Related Porous Materials
Synthesis and Structure, John Wiley \& Sons (Asia) Pte Ltd, Singapore.

Yudhastuti, R., (1993), Studi Kemampuan Zeolit untuk Menurunkan Jumlah Kuman-Kuman Coliform Air Sungai Ciliwung di Jakarta, Tesis, Fakultas Kesehatan Masyarakat, Universitas Indonesia, Indonesia, 1993.

Yusof, A.M., Nizam, N.A, and Rashid, N.A., (2010), Hydrothermal Conversion of Rice Husk Ash to Faujasite-types and NaA-type of Zeolite, J Porous Material, 17, pp. 39-47. 